\title{
AUTHORIZED CAPITAL AS A RISK MANAGEMENT TOOL IN EMERGING ECONOMIES. THE CASE OF POLAND
}

\begin{abstract}
This paper addresses the strength of the incentives from both supervisors and market players to use authorized capital application as a risk management tool. The study compares the motivational factors for the financial market in transition and market supervisors. It analyses the interaction between motivation and the application of authorized capital as a risk management tool. We challenge the hypothesis that there is a weak statistical relationship between goodwill rates and the existence of authorized capital instruments for quoted companies, and a weak statistical relationship between bank allowance and authorized capital instruments. Through the application of logit procedures to companies quoted on the Warsaw Stock Exchange, we reach findings based on 386 listed and domiciled entities in Poland, as quoted on 30 December 2011. We conclude that a semi-effective market suffers from efficiency in the adoption of authorized capital as a risk management tool. We indicate that market forces are overridden by supervisory requirements; thus, the promotion of effective risk management tools is positively associated with regulator and supervisory activities.
\end{abstract}

Key words: authorized capital, risk, Basel, logit, control, market supervision.

\section{INTRODUCTION}

This article analyses the application of authorized capital for risk management purposes, in public companies.

The current structure of the authorized capital instruments provided in the deeds of entities listed on the primary market of the GPW (Giełda Papierów Wartościowych w Warszawie - Warsaw Stock Exchange, hereafter „WSE”) indicates that out of 386 companies listed on 31st December 2011, 115 bestow the right of authorized capital issue on their management board. Consequently, one third of these entities' shareholders allocate substantial control and power to their boards. This observation is deemed to provide a sound basis for more detailed research.

\footnotetext{
* Ph.D. hab., Warsaw School of Economics, Collegium of Business Administration, Institute of Corporate Finance and Investments.

${ }^{* *}$ Ph.D., Warsaw School of Economics, Collegium of Business Administration, Institute of Corporate Finance and Investments.
} 
The paper addresses the time shift between risk measurement against the entities' ability for the timely gathering of a capital base, as the risk implied within the risk assessment model is different to the one implied within the capital contingence plan. The aim of this paper is to investigate the magnitude of the incentives provided by both the market itself and supervisors to persuade owners to provide managers with rapid access to core capital. We aim to challenge two relatively difficult to observe processes. First, risk management stemming from the previous characteristics of the company as manifest in its behavior, and second, the impact of the Basel Committee recommendations for supervision and market players. The paper also concerns the rationality behind supervisor intervention on the market, as well as ultimate shareholder transfer of ownership control to management.

Our finding are that the tools typically used for the public and supervised segment of the market are unused for the unsupervised and OTC segments.

To date, there appears to be no similar research, either in terms of scope or geographical region; thus, this paper may provide an initial insight into this research issue itself.

The article is structured as follows: Section two provides a literature review; the third section introduces the methodology; the fourth section describes the data, variables and model; the fifth section provides the results and discussion; and the sixth offers a conclusion.

\section{LITERATURE REVIEW}

Authorized capital is a relatively new construction in the Polish legal system. Authorized capital is the amount of capital declared by shareholders which is unpaid at the moment of declaration, and might be claimed by the management during the declaration period. It was introduced in 2001 with a new company code. Authorized capital allows an increase in the share capital following a management board resolution. It is however a different construction to that common to the Anglo-American legal system, as there is no limit above which the company cannot issue capital [Maciąg 2012: 13]. The granting of authorization to the management board is done through a change in company deeds. The conditions for this amendment to the deeds are rigorous. Nonetheless, „this way of enhancement the share capital easies the quick offering and gathering of capital at suitable moment of time for the company" [Kidyba 2011: 843]. The transfer of general meeting authority to the management, in terms of allowing them the selection of date, portfolio of new shareholders, and terms of payments, results in an actual transfer of power. Since such a shift of power might result in abuse and fraud, to avoid conflict on the principal-agent line a number of the check-points were created. This limitation 
relates principally to scope, the form of rights granted and the execution of rights proceeding from the new issue.

An additional limitation relates to the time aspect. The empowerment of the management board is time limited and must not exceed three years [Art. $444 \S 1$ $\left.\mathrm{Ksh}^{1}\right]$, however it can be reapplied [§2]. Another board is then drawn up with a relative amount - Art. $444 \S 3$ imposes a limitation on the authorization of capital value up to $3 / 4$ of shareholder capital (basic capital) from the date of the resolution.

The limitation also relates to the payment method for the subscribed capital. Subscription cannot be settled with the company's own funds [Kidyba 2011: 847], the option of a contribution in kind must be expressed with direct empowerment authorized by a general meeting of shareholders [Art. $444 \S 4$ Ksh]. An unconditional ban is then imposed over the granting of personal rights to the prospect subscribed to, both in terms of share preferences, extra services or additional rights [Art. $444 \S 6 \mathrm{Ksh}$ ]. The change in company deeds requires a resolution at the shareholders' general meeting. This resolution requires extraordinary conditions, both in terms of votes and quorum. In order to be valid, the resolution requires that $3 / 4$ of all votes be subject to a quorum of half of shareholding capital (in the case of a public company, that is $1 / 3$ of the shareholding capital) [Art. $445 \S 1 \mathrm{Ksh}$ ].

The Basel Committee indicated with its Accords, the need for capital maintenance and public disclosure. Since the introduction of pillar three with Basel II, the committee has recommended that, within the Supervisory Review and Assessment Process, there is a need for an adequate capital level it (Section 750) provides:

„Supervisors should also consider the extent to which the bank has provided for unexpected events in setting its capital levels. This analysis should cover a wide range of external conditions and scenarios, and the sophistication of techniques and stress tests used should be commensurate with the bank's activities" [Committee 2004: 163].

The review strengthens disclosure requirements under the Basel II framework. Capital qualitative and quantitative disclosure was introduced together with an enhanced portfolio of the available measurement methods [Gonda 2004; Horvatova 2008; Jimenez Rodriguez, Feria Dominguez Marin 2009]. The committee required disclosure of, among others, summary information on the terms and conditions of the main features of all capital instruments; i.e. the amount of Tier 1 capital, the total amount of Tier 2 and Tier 3 capital, other deductions from capital and total eligible capital [Committee 2004: 179]. Basel III enhanced capital disclosures, mainly by providing a full reconciliation of all regulatory capital elements back to the balance sheet in the audited financial statements and by giving a description of the main features of

\footnotetext{
${ }^{1}$ Ksh is the abbreviation of the Polish Commercial Code.
} 
the capital instruments issued. Additionally, by imposing requirements that supervised entities make available on their websites, the full terms and conditions of all instruments are included in regulatory capital [Bikker, Metzemakers 210: 27]. A separate disclosure is imposed by accounting standards, leading to the availability of risk management tools as authorized capital being public information.

The above promotes capital contingency, maintenance planning and capital management. The capital maintenance plan is subject to standardization efforts [Berlińska, Berliński 2012; Gos 2012; Stępień 2010]. A substantial effort however is imposed on business contingency and capital contingency plans, especially in term of the timely provision of rescue capital.

According to the author's knowledge, there has been no research conducted in Poland concerning the application and motivation of authorized capital implementation for public companies in conjunction with Basel II or III. It appears evident, from both the nature of the legal instruments and the motivation behind the strengthening of the capital base, as promoted by the Basel Committee, that the authorized capital would be a tool commonly found in a company's risk management portfolio.

The response of the supervised entity to the excessive risk exposures under the Basel regime could yield multi-fold behavior. The entity might increase the capital available for risk cover, or limit its risk exposure by derecognition of risky assets, or trade between risk assessment methods. The method of arbitrage is, however, subject to the authority's discretion, thus it is slow to respond to emergency injections, and its application results in insignificant changes to capital. The expected changes resulting from different methods and capital requirements are in the range of a few percentage points, as shown by Teply [2012] for advance measurement methods, versus basic indicators for operational risks to the banking sector.

Those market forces for capital restructuring are primarily linked to liquidity requirements, and current and prospective capital expenditure. Thus, to finance capital expenditure a company must use their internally generated resources (mainly retaining earnings). Brogi [2010] indicates that the ,aggregate pay-out of the Italian banking system showed a fluctuating trend" [Brogi 2010: 237] in contexts where market conditions differ. Whereas Fama and French [2001] outline the fact that the long term trend with dividends pay-out ratio is rather negative. They favor a repurchase policy [Brockman et al. 2008]. The dividend support is strongly linked with the entity's ability to generate a positive cash flow during downturns [Adjaoud et al. 2010], which is not necessarily a justified assumption [El-Sady et al. 2012].

External resources are linked to tools such as the capital issues affecting the market or involvement of the organization in financial restructuring processes (mergers and acquisitions or management buy-out, etc.). These procedures are 
usually complex in terms of motivation [Smirnova 2014] and also time consuming. The possible discount for control transfer, even at 25\% [Dragota et al. 2013], does not substantially outperform IPO initial price discounting [Baran, Tuzimek 2008]. In addition, Adamska [2008] indicates a significant global fluctuation in IPO values over time. The stress on the entity imposed by the substantial lack of liquidity or significant losses is buffered by the availability of capital, but not as efficiently as would be ideal [Ojo 2010]. The actual loss of liquidity and capital is financed by accounting reserves, instead of by unrecognized balance sheet items, as proposed by the social reporting stream [Bebbington et al. 2008]. Unrecognized intangible assets (mainly goodwill, social capital, reputation, etc.) are unlikely to be discounted in the form of cash, without substantial write-downs in times of stress. Taking the above into account, authorized capital is a tool that directly relates to the ultimate shareholders, and which is a relatively quick and simple solution for contingence capital gathering.

We share the opinion of Wagner and Garner [2010] that the mutual implementation of Basel and fair value accounting standards paradoxically: ,impose a positive feedback effect that destabilizes the financial system, increasing systemic risk. Ironically, the primary rationale for capital adequacy requirements is the containment of systemic risk" [Wagner, Garner 2010: 38].

However, this spreads the accounting value and market value proxies and the market's willingness to provide additional equity to the company and its relative power to issue the equity and maintain ongoing operations without approaching the ultimate owner. This effect is enhanced by the global imbalance caused by a growing surplus of capital that cannot find adequate space for gains in the real economy [Šikula 2009]. Depreciation of the distance between the market and accounting valuations shrinks the company's ability to gather capital, as well as indicating the solvency context of a capital based decrease. Thus, the relative decrease of the goodwill rate, measured as a relationship between market value and accounting equity value over the equity value proxies, places pressure on the implementation of the capital conservation tools. The above-mentioned behavior is motivated by the market, principally the stock exchange, where the market values are observable. This observation and Cao et al.'s [2013] research provides the foundation for the statements that there should be a trade-off between authorized capital and public offerings. The management's capacity to collect the contingent capital in a timely manner differs for both strategies. At a point when the company itself is well recognized by the market, the chance of the prompt collection of additional capital issues is substantially higher than would be the case during a financial turndown.

The two above mentioned channels of capital conservation, i.e. mainly supervisory and market based, coexist. The aim of this paper is to assess the strength of the drive for capital conservation on the public market. Thus, it is 
hypothesized that there will be a relationship between the goodwill rate and the type of industry (split between supervised and unsupervised entities) and provisioning for authorized capital.

The set of hypotheses tested are presented below:

- Null hypothesis is $\mathrm{Hl}_{0}$ : there is not a strong statistical relationship between the goodwill rate and the existence of an authorized capital instrument for the quoted companies.

- Alternative hypothesis $\mathrm{HI}_{l}$ : there is a strong statistical relationship between the goodwill rate and the existence of an authorized capital instrument for the quoted companies.

Meanwhile, the set of hypotheses for structural behavior are as follows:

- Null hypothesis is $\mathrm{H}_{2}$ : there is not a strong statistical relationship between the bank allowance and the authorized capital instrument.

- Alternative hypothesis is $H 2_{1}$ : there is a strong statistical relationship between the bank allowance and the authorized capital instrument.

\section{METHODOLOGY}

To verify the null hypotheses, a logistic regression was used, combined with a simple mean comparison. The logistic model provides a method for modeling a binary response variable. Assuming variable $Y$ is a binary variable, at values 1 success, 0 failure, then the logistic regression model is given by:

$$
\mathrm{P}\left(Y=1 \mid x_{1}+x_{2} \ldots x_{n}\right)=\frac{e^{a_{0} \sum_{i-1}^{k} a_{i} x_{i}}}{1+e^{a_{0} \sum_{i-1}^{k} a_{i} x_{i}}}
$$

where, $\mathrm{a}_{\mathrm{i}}, \mathrm{i}=0 . . \mathrm{k}$ are regression coefficients and $\mathrm{x}_{1} \ldots \mathrm{x}_{\mathrm{k}}$ are the independent variables.

The function $\mathrm{P}$ converses the scalar $\mathrm{X}$, where $\mathrm{X}=\left(\mathrm{x}_{1}, \mathrm{x}_{2}, \ldots, \mathrm{X}_{\mathrm{k}}\right)$ represents the probability of success. The relation:

$$
\frac{\mathrm{P}(\mathrm{X})}{\mathrm{P}(\operatorname{not} \mathrm{X})}
$$

is equivalent to:

$$
\frac{\mathrm{P}(\mathrm{X})}{1-\mathrm{P}(\mathrm{X})}
$$


and is called the odds ratio (Odds); it shows the chance of success against failure. Thus, the relation:

$$
\operatorname{logit} \mathrm{P}=\ln \frac{\mathrm{P}}{1-\mathrm{P}}=\ln \frac{\mathrm{P}(Y=1)}{1-\mathrm{P}(Y=1)}
$$

by substitution $\mathrm{P}(\mathrm{Y}=1)$ with $(1)$, the logit form of logistic regression takes the form of:

$$
\operatorname{logit} \mathrm{P}=a_{0}+\sum_{i=1}^{k} a_{i} x_{i}
$$

and

$$
\text { Odds }=e^{a_{0} \sum_{i-1}^{k} a_{i} x_{i}}
$$

when as $\mathrm{f}(x)=a_{0} \sum_{i-1}^{k} a_{i} x_{i}$

$$
\text { Odds }=\mathrm{e}^{\mathrm{f}(\mathrm{x})}
$$

Assuming a model has only one variable, and $\mathrm{f}(x)$ is equal to $\mathrm{a}_{0}+\mathrm{a}_{1} \mathrm{x}$, if the explanatory variable $x$ increases by one unit from $x$ to $x+1$, the odds ratio changes from

$$
e^{a_{0}} e^{a_{1} x}
$$

to

$$
e^{a_{0}} e^{a_{1}(x+1)}=e^{a_{0}} e^{a_{1} x} e^{a_{1}}
$$

The odds ratio (OR) is therefore

$$
\frac{e^{a_{0}} e^{a_{1} x} e^{a_{1}}}{e^{a_{0}} e^{a_{1} x}}=e^{a_{1}}
$$

The odds ratio is a linear function of $X$.

$$
\operatorname{logit}(\mathrm{P})=\log _{\mathrm{e}}\left[\frac{P}{1-P}\right]=a_{0}+a_{1} x_{1}+\cdots+a_{1 m} x_{m}
$$

Thus, each $a_{i}$ indicates the one unit effect for the independent variable change to the odds ratio; therefore, the higher the $a_{i}$, the higher the prediction ability of the independent variable. 
The significance of each of the variables measures the strength of the specific variable to effect a probability change. The logit parameters are organized using a maximum likelihood function; its assessment is sensitive to sample size, such that, some authors recommend a range of 100-500 observations [Stanisz 2007: 226]. Thus, we link our hypothesis, which is set against the quality of the model itself, with significance of the variables investigated.

\section{DATA SET, VARIABLES AND THE ANALYTIC MODEL}

For all the listed companies on the primary market, the data, as of $31^{\mathrm{st}}$ December 2011, were gathered from the „Ceduła Giełdy Papierów Wartościowych w Warszawie" [Official publication of the WSE, no. 251(4717)]. The data for capital authorization were manually gathered from the specific deeds published on the company's website of listed companies.

The time span for the observation was limited to the year 2011, since the implementation of the Basel II Accord for the Polish broker-dealer market took place on 1 January 2010 [Staszkiewicz 2014]. The first data for the response of the broker dealers market were accumulated during 2010 and 2011.

The definition of the variables is shown in Table 1 .

Table 1. Variable definitions

\begin{tabular}{|l|l|l|}
\hline \multicolumn{1}{|c|}{ Name } & \multicolumn{1}{|c|}{ Definition } & \multicolumn{1}{|c|}{ Remarks } \\
\hline \hline ACapital & $\begin{array}{l}\text { Authorized capital binary variable with } \\
\text { a value of 1 for the inclusion of the } \\
\text { target capital instruments in the } \\
\text { company's deed, otherwise 0. }\end{array}$ & Data manually collected by authors \\
\hline MV & $\begin{array}{l}\text { Market value of the company as of 31 st } \\
\text { December 2011, non-negative number } \\
\text { in millions of zł. }\end{array}$ & Ceduta [official Polish s stock listing] \\
\hline BV & $\begin{array}{l}\text { Accounting book value equal to the } \\
\text { company's net equity in millions of zł. }\end{array}$ & Ceduta \\
\hline GWR & $\begin{array}{l}\text { Goodwill rate being a fraction equal to } \\
\text { (MV-BV)/BV. }\end{array}$ & Authors' calculation \\
\hline Bank & $\begin{array}{l}\text { Supervised entities under the BASEL II } \\
\text { regime being banks and investment } \\
\text { companies. }\end{array}$ & $\begin{array}{l}\text { Mutual funds, insurance companies, } \\
\text {,SKOK” were excluded due to their } \\
\text { non-BASEL II status, the broker-dealers* } \\
\text { were excluded due to different } \\
\text { implementation times. }\end{array}$ \\
\hline
\end{tabular}

* The entire set of data is supervised under Basel II regime IDM S. Due to the significant written off intangibles and the application of the contingency capital plan, subsequently the observation was considered to be an outlier and eliminated from the later model [Staszkiewicz 2013].

Source: Authors'. 
Other industry types were taken into consideration, but were ultimately excluded from the final model due to their insignificance. Taking into account the above, the analytical form of the model was as follows:

$$
\text { Logit }(\text { ACapital })=a_{0}+a_{1} \text { Bank }+a_{2} \text { GWR }
$$

The calculation was performed by the application of Statistica version 10 [StatSoft 2010], Gretlversion 1.9.11 [Cottrell, Luchett 2012] and R version 2.15.3 [Team 2013].

\section{RESULTS AND DISCUSSION}

Table 2 shows the effect of market pressure on listed companies to apply the authorized capital tool.

Table 2. Comparison of mean values for goodwill rates among companies with authorized and unauthorized capital

\begin{tabular}{|l|c|c|}
\hline \multicolumn{1}{|c|}{ Authorized } & GWR - Mean & GWR - Std.Err. \\
\hline \hline No & 0.210 & 0.185 \\
\hline Yes & -0.153 & 0.284 \\
\hline
\end{tabular}

Source: Authors' calculation.

The F-statistic is: $\mathrm{F}(1,384)=1.15, \mathrm{p}=0.28$. The $\mathrm{p}$ value here indicates the universal homogeneity of the quoted companies on the WSE in terms of goodwill rate between those implementing and not implementing the authorized capital instrument. It should be noted however that the population was only limited to Polish based entities, thus, the conclusions in respect of foreign assets were rather indicative, as the sample selection did not necessarily meet the randomization requirement.

Consequently, the impact of power on the decay of the financial position does not seem to be significant on the WSE, which is contradictory to the methodological analysis. The argument might be raised that the mean comparison is a statistical tool. However, the level of equity balance represents the dynamic portion of the process, that between the dividend repayment and the entity's ability to accumulate resources. Secondly, the process of changing the company deed is rather long term; it involved substantial legal and organizational effort, thus its variability within the population is rather small in regard to time. The last proxy relates to market value. This proxy might reveal a significant time-dependency variation and leave room for additional research. 
In this particular study, a change in market value parameters (e.g. replacement with an average or any other model) requires a judgment based on relevant parameter estimation, time lag, form of model, etc. The loss of the time dimension for this proxy tends to be compensated for by the sample size. The increase in the model risk and error does not necessarily outweigh the loss of simplicity in the assessment.

The second stage of the procedures involved the determination of a portfolio of characteristics relating to the type of listed companies, their goodwill ratio (GWR) and the probability of applying the authorized capital tools. The following sector splits were taken into account: food, light, wood and paper, chemicals, pharmaceuticals, plastic materials, oil and gas, building materials, construction, electro-engineering, metals, automobiles, raw materials, banking, insurance, developers, capital market, other finance, retail trade, wholesale trade, IT telecoms, energy, hotels and restaurants, media, other services and other industries. With the exception of banking, no other industry cross section was found to be significant ${ }^{2}$.

For logic regression, the authorized capital probability was explained using the two variables, goodwill ratio and bank. The specification of the model and parameters' estimation is shown in Table 3.

Table 3. Model estimation for ACapital (Authorized capital)

\begin{tabular}{|l|r|c|c|}
\hline & Constant B0*** & Bank** & GWR \\
\hline \hline Estimations & $\mathbf{- 0 . 9 0 1}$ & $\mathbf{1 . 0 4 3}$ & -0.038 \\
\hline Standard error & $\mathbf{0 . 1 1 5}$ & $\mathbf{0 . 5 3 0}$ & 0.039 \\
\hline $\mathrm{t}(383)$ & $\mathbf{- 7 . 8 4 6}$ & $\mathbf{1 . 9 6 7}$ & -0.977 \\
\hline $\mathrm{P}$ & $\mathbf{0 . 0 0 0}$ & $\mathbf{0 . 0 5 0}$ & 0.329 \\
\hline -95\%CL & $\mathbf{- 1 . 1 2 7}$ & $\mathbf{0 . 0 0 0}$ & -0.114 \\
\hline +95\%CL & $\mathbf{- 0 . 6 7 5}$ & $\mathbf{2 . 0 8 5}$ & 0.038 \\
\hline Chi ${ }^{2}$ Wald & $\mathbf{6 1 . 5 5 8}$ & $\mathbf{3 . 8 6 9}$ & 0.954 \\
\hline P & $\mathbf{0 . 0 0 0}$ & $\mathbf{0 . 0 4 9}$ & 0.329 \\
\hline Odds ratio (unit ch) & $\mathbf{0 . 4 0 6}$ & $\mathbf{2 . 8 3 7}$ & 0.963 \\
\hline -95\%CL & $\mathbf{0 . 3 2 4}$ & $\mathbf{1 . 0 0 0}$ & 0.892 \\
\hline +95\%CL & $\mathbf{0 . 5 0 9}$ & $\mathbf{8 . 0 4 7}$ & 1.039 \\
\hline Odds ratio (range) & & $\mathbf{2 . 8 3 7}$ & 0.071 \\
\hline -95\%CL & & $\mathbf{1 . 0 0 0}$ & 0.000 \\
\hline +95\%CL & & $\mathbf{8 . 0 4 7}$ & 14.627 \\
\hline
\end{tabular}

**Significant at $0.05 ; * * *$ Significant at less than 0.01

Source: author's calculations.

${ }^{2}$ We do not provide detailed calculations in this paper. 
The number of 1's:115 (30\%) and number of 0's:271 (70\%). Dependent variable: ACapital (Authorized capital). Independent variables: 2: Bank and CRW. Loss function is maximum likelihood. Model fitting measured with $-2 * \log ($ Likelihood): for this model $=465,3$ intercept only $=470,2$ Chi-square $=4,87 \mathrm{df}=2$ with $\mathrm{p}=0.087$, at number of observation $\mathrm{N}=386$.

Source: Authors' calculations.

The logit model parameters' estimation of the logistic regression are presented in this table. The model itself indicates a weak fit, at the $10 \%$ significance level, this might explain the provability and inclusion of the authorized capital tool in the listed companies. The parameters are significant only for the intercept and banks, while the GWR stays insignificant. The model fit, in terms of odds classification, yields a $70 \%$ success rate, however, the misclassification of cases is substantial, in terms of „1”, as shown in Table 4.

Table 4. Classification of cases

\begin{tabular}{|l|c|c|c|c|}
\cline { 3 - 5 } \multicolumn{2}{c|}{} & Pred. & Pred. & Percent \\
\cline { 3 - 5 } \multicolumn{2}{c|}{} & 0 & 1 & Correct \\
\hline Actual & 0 & 264 & 7 & 97.42 \\
\hline Actual & 1 & 106 & 9 & 7.83 \\
\hline
\end{tabular}

Source: Authors' calculations.

Our results confirm the initial null hypothesis, that there is a not a strong statistical relationship between the goodwill rate and the existence of the authorized capital instrument for the quoted companies. We found that the second null hypothesis, that there is not a strong statistical relation between the bank allowance for the authorized capital instrument, is rejected at a reasonable confidence level, subject to the quality of the model itself.

Despite the relative weakness of the model fit, it indicates the outperformance of the supervised sector over the remainder of the market. It is natural to accept that the influence is remote from the functional relationship, due to its nature. The impact of the supervisors is more a soft recommendation than a specific adjustment decision for authorized capital application. The results guide us to the observation that the relative power of the market for the promotion of authorized capital as a risk management tool is somewhat limited. This is probably due to time and formal constraints, as well as transaction costs, as observed by Serraqueiro and Rogão [2009] among others. Another explanation might be derived from the interconnection between liquidity and capital requirements, which states that greater capital hampers the creation of liquidity [Horváth at al. 2012]; thus, the market aims to strike a balance between 
contradictory forces. The strength of the market's promotional force is also associated with the form of the market, as the WSE is considered a semi-effective market [Divis and Teply 2005; Buczek 2005; Dobija and Klimczak 2010]. Conversely, the appearance of tools on the side of the supervised banking sector indicates a substantial influence on best practice [Marcinkowska 2012], and a formal and informal influence from supervisors.

\section{CONCLUSION}

Our study concludes that a semi-effective market suffers from efficiency in the adoption of authorized capital as a risk management tool. In contrast, the influence of supervisors and regulations enhance the motivation for entities to apply authorized capital as risk management tools.

We suffered from a lack of intensive research on this specific topic as related to the WSE. We therefore acknowledge the limits on the generalization of the research towards other markets, due to the different nature of the authorized capital implemented in Poland and abroad, as well as the implementation of the Basel Accord. When concluding, we must consider the limitations of the procedure itself. We allowed for a weak technical fit of the model, due to data and time constraints; moreover, the population is analyzed based on a cross-sectional analysis, while a panel data study might be more useful for future studies. Regardless of its limitations, our study indicates the need for the country and its authorities to promote the application of risk management tools. As of the date of completion of this research, the WSE is not efficient enough to promote a significant application of these tools in isolation.

\section{REFERENCES}

Adamska A., 2008, Publiczny rynek pierwotny akcji $w$ Polsce na tle tendecji światowych, In: S. Buczek, A. Fierla (eds.), Rynek kapitałowy w Polsce $i$ na świecie - jak madrze inwestować, Warsaw.

Adjaoud F., Ben-Amar W., 2010, Corporate Governance and Dividend Policy: Shareholders' Protection or Expropriation?, Journal of Business Finance \& Accounting 37(5-6), 648-667.

Baran A., Tuzimek R., 2008, Zjawisko premii inwestorskiej w Polsce w latach 2004-2007 na tle doświadczeń rynkow rozwiniętych in Wspótczesne finanse, In: D. Dziawgo (ed.), Stan perspektywy rozwoju rynku finansowego, Torun, 461-470.

Bebbington J., Larrinaga C., Moneva J., 2008, Corporate social reporting and reputation risk management, Accounting Auditing and Accountability Journal 21(3), 337-367.

Berlińska J., Berliński A., 2012, Zarzqdzanie ciagłościq działania w świetle wymagań BS 25999, Logistyka 5, 284-289. 
Bikker J., Metzemakers P., 2010, Basel III: A Global Regulatory Framework for More Resilient Banks and Banking Systems, Basel Committee.

Brockman P., Howe J. , Morta 1 S., 2008, Stock market liquidity and the decision to repurchase, Journal of Corporate Finance 14(4), 446-459.

Brogi M., 2010, Capital adequacy and dividend policy: Evidence from Italian banks, Le Banche Italiane sono speciali?, In: G. Bracchi, D. Masciandaro (eds.), XV Rapporto sul sistema finanziario italiano „Le banche italiane sono speciali? Nuovi equilibri tra finanza, imprese e Stato", Fondazione Rosselli, Edibank, Milano, 219-248.

Buczek S. B., 2005, Efektywność informacyjna rynków akcji: teoria a rzeczywistość, Szkoła Główna Handlowa.

Cao L., Xia X., Wang Y., 2013, Market Timing with Security Offering Regulations: Evidence from Private Placements of Chinese Listed Firms, Emerging markets finance and trade 49(2), 91-106.

Committee, 2004, International Convergence of Capital Measurement and Capital Standards A Revised Framework, Basel Committee on Banking Supervision.

Cottrell A., Luchett R. ,Jack.”, 2012, Gretl.

Divis K., Teply P., 2005, Information efficiency of Central Europe stock exchanges, Finace a uver-czech journal of economics and finance 55(9-10), 471-482.

Dobija D., Klimczak K. M., 2010, Development of Accounting in Poland: Market Efficiency and the Value Relevance of Reported Earnings, International Journal of Accounting 45(3), $356-374$.

Dragota V., Lipara C. Ciobanu R., 2013, Agency Problems and Synergistic Effects in Romania: The Determinants of the Control Premium, Finace a uver-czech journal of economics and finance 63(2), 197-219.

El-Sady H., Hamdy H., 2012, Dividends Policies in an Emerging Market, International Review of Business Research Papers 8(2), 12-28.

Fama E. F., French K. R., 2001, Disappearing dividends: Changing firm characteristics or lower propensity to pay?, Journal of Financial Economics 60(1), 3-43.

Gonda V., 2004, Banking supervision in light of Basel II, Ekonomicky casopis 52(6), 647-657.

Gos W., 2012, Doptaty do kapitatu w spótce $z$ o.o., Zeszyty Naukowe Uniwersytetu Szczecińskiego. Finanse. Rynki finansowe. Ubezpieczenia 45, 37-51.

Horváth R., Seidler J., Weill L., 2012, Bank capital and liquidity creation granger-causality evidence, Macroprudential Research Network Working Paper Series, Frankfurt am Main.

Horvatova E., 2008, Capital adequacy conception of banks and investments firms in conditions of European Union, Ekonomicky Casopis 56(6), 582-597.

Jimenez Rodriguez E. J., Feria Dominguez J. M., Martin Marin J. L., 2009, Economic capital for operational risk: An application using the loss distribution approach, Revista espanola de fianciacion y contabilidad - Spanish Journal of finance and accounting 38(141), 37-56.

Kidyba A., 2011, Kodeks spótek handlowych. Komentarz, t. II. 8th ed. Warszawa.

Maciąg M., 2012, Konstrukcja kapitału docelowego w prawie polskim na tle wybranych praw obcych, C.H. Beck, Warszawa.

Marcinkowska M., 2012, Realizacja zasad tadu korporacyjnego przez polskie banki, Zarządzanie Finansami 10(4), 537-567.

Ojo M., 2010, Preparing for Basel IV - Why Liquidity Risks Still Present a Challenge to Regulators in Prudential Supervision, Social Science Research Network.

Serrasqueiro Z. M. S., Rogão M. C. R., 2009, Capital structure of listed Portuguese companies: Determinants of debt adjustment, Review of Accounting and Finance 8(1), 54-75.

Šikula M., 2009, Kritická miera rozporov civilizácie a globálna ekonomická, Ekomicky casopis 8, $732-755$.

Smirnova Y., 2014, Motives for mergers and acquisitions in the banking sector of Kazakhstan, In: J. Karlovitz (ed.), Economcs questions, issues and problems, 79-98.

Stanisz A., 2007, Przystępny kurs statystyki z zastosowaniem STATISTICA PL na przykładach z medycyny, Vol. II, StatSoft, Kraków. 
Staszkiewicz P., 2014, Sprawozdawczość ostrożnościowa i finansowa firm inwestycyjnych, Wolter Kluwers, Warszawa.

Staszkiewicz P., 2013, Verification of the disclosure lemma applied to the model for reputation risk for subsidiaries of non-public group with reciprocal shareholding on Polish broker-dealers market, In: K. Jajuga, W. Ronka-Chmielowiec (eds.), Inwestycje finansowe i ubezpieczenia - tendencje światowe a rynek polski, Wydawnictwo Uniwersytetu Ekonomicznego we Wrocławiu, Wrocław, 337-346.

StatSoft, 2011, Statisitca.

Stępień T. W., 2010, Plan Ciagłości Działania, Bank 5, 64-65.

Team R. C., 2013, R: A language and environment for statistical computing, Foundation for Statistical Computing, Vienna.

Teply P., 2012, The Application of Extreme Value Theory in Operational Risk Management, Ekonomicky casopis 60(7), 698-716.

Wagner A., Garner D., 2010, Fair Value Accounting - Fact Or Fancy?, Journal of Business and Economic Research 8(11), 35-39.

Agata Adamska, Piotr Staszkiewicz

\section{KAPITAŁ DOCELOWY JAKO NARZĘDZIE ZARZĄDZANIA RYZYKIEM W GOSPODARKACH WSCHODZĄCYCH. PRZYPADEK POLSKI}

Niniejszy artykuł odnosi się do siły oddziaływania zarówno organów nadzoru, jak i samych uczestników rynku na wykorzystywanie kapitału docelowego jako narzędzia zarządzania ryzykiem. Zostały w nim zestawione czynniki istotne na rynku finansowym w okresie transformacji. W artykule analizie poddano interakcje między tymi czynnikami a stosowaniem kapitału docelowego jako narzędzia zarządzania ryzykiem. Stawiamy hipotezy, że istnieje słaba zależność statystyczna między wartością goodwillu a występowaniem kapitału docelowego w spółkach publicznych oraz słaba statystyczna zależność między statusem podmiotu jako przedsiębiorstwa bankowego a występowaniem w nim kapitału docelowego. Zastosowanie procedur logitowych do danych dotyczących spółek notowanych na Giełdzie Papierów Wartościowych w Warszawie, pozwoliło sformułować wnioski odnoszące się do wszystkich 386 podmiotów domicylowanych Polsce, notowanych 30 grudnia 2011 r. Stwierdziliśmy, że częściowo efektywny rynek nie wymusza skutecznie zastosowania mechanizmu kapitału docelowego jako narzędzia zarządzania ryzykiem. Wskazujemy, że siły rynkowe są zastępowane wymogami nadzorczymi; dlatego rozwój skutecznych narzędzi zarządzania ryzykiem jest związany z aktywnością regulatora i nadzorcy rynku finansowego.

Słowa kluczowe: kapitał docelowy, ryzyko, Bazylea, kontrola, nadzór nad rynkiem. 